
Chapter 21

\title{
CASE HISTORY OF THE CAPE COD CANAL
}

\author{
John E. Allen \\ Chief, Engin eering Division \\ New England Division, Corps of Engineers \\ Boston, Massachusetts
}

No more interesting or appealing subject than the cape cod Canal could be assigned to one who is engaged in the study and development of navigation in New Ingland. This sea-level canal, located 50 miles south of Boston at the narrow neck of land joining Cape cod to the mainland, principaliy serves coastwise shipping to and from Boston and Northerm New England. While it was only completed in 1940, no one should entertain the thought that it is of recent origin.

Construction of the Cape Cod Canal was first considered and explored in 1623 by Captain Nyles Standish of the original Plymouth Colony. He traversed the route by boat and portage to reach the south shore of the Cape. There a trading post had been set up to encourage coumerce with Dutch merchantmen safling to and from New Amsterdam or New York. Undoubtedly, Captain Standish had the typical soldier's aversion to walking if you could ride.

The idea of a canal is immediately suggested by the geography of the area. A low swale of alluvial formation, nownere more than 30 feet above mean sea level, crosses the neck of land where Cape Cod joins the mainland. The Monument River drained this valley to the south, and Scusset River to the north, and their headwaters were not more than three-fourths of a mile apart. Surveys, investigations, and studies recomending construction of a canal followed in steady procession for three centuries. It has been said that, every grain of sand along the proposed route has been made the victim of detailed study. The only obstacle to its construction was that of "where to find the funds with which to build it a" New England, as many of you appreciate, bas never enjoyed the reputation for hastily adopting new improvements, particularly when money was inrolved.

To avoid the problem of strong tidal currents all proposals made up to 1862 included plans for a lock canal, but in that year the earliest known suggestion for a sea-level waterwsy was advanced. Generally, the proposals all followed the same route, although 4 other routes ware seriously considered. Three proposals were based on a canal about 18 miles to the east from Hyannis to Barnstable; and one even further east, where the Cape hooks to the north at Orleans. (See Figure 1.) Construetion of a sea-level canal from Buzzards Bay to Sandrich was finally undertaken by a private company in 1909 and completed in 1916. Thi. Canal, 25 feet deep and 100 feet wide, cost $\$ 13,000,000$. The southerly approach through the shoal water of upper Buzzards Bas bent to the east of Hog Island and Mashnee Island, closely following the shore of the 


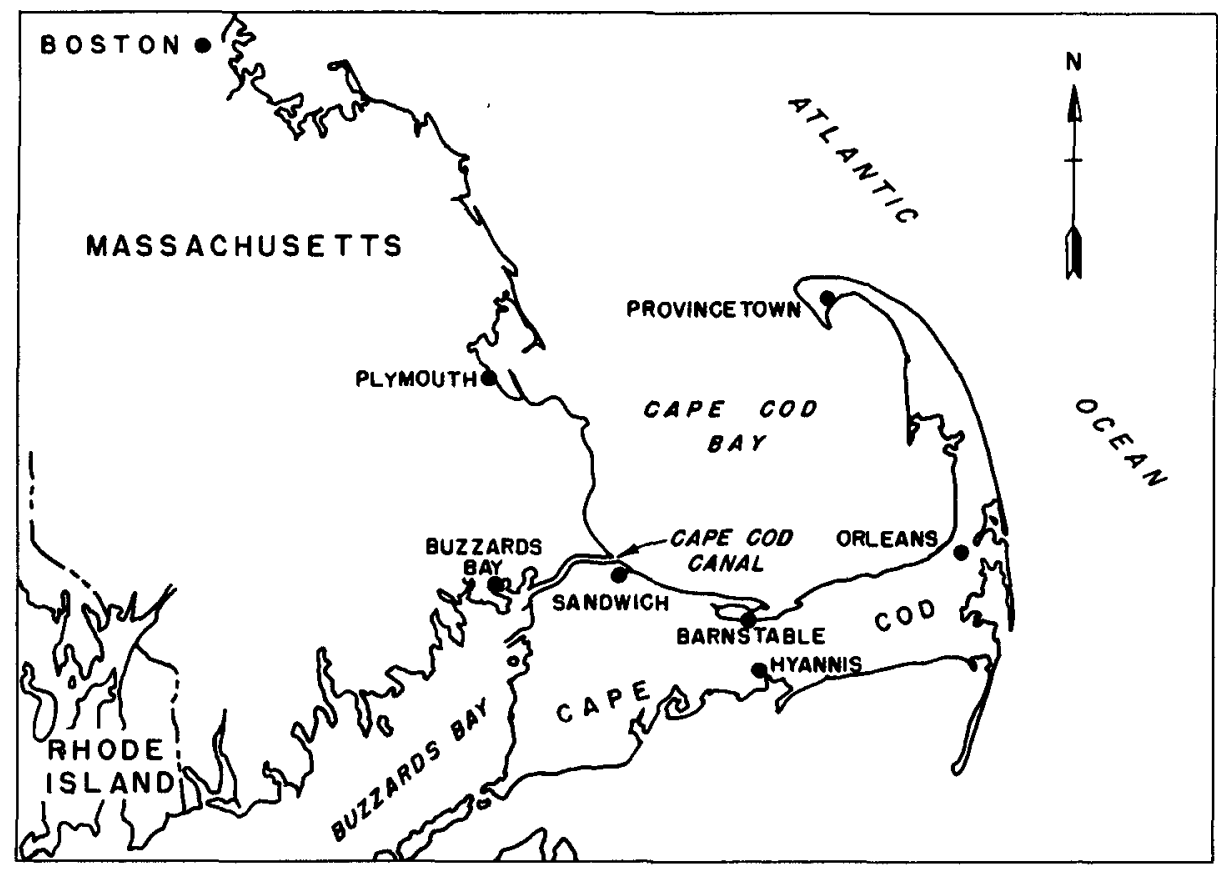

Fig. 1. Vicinity map - Cape Cod, Massachusetts.

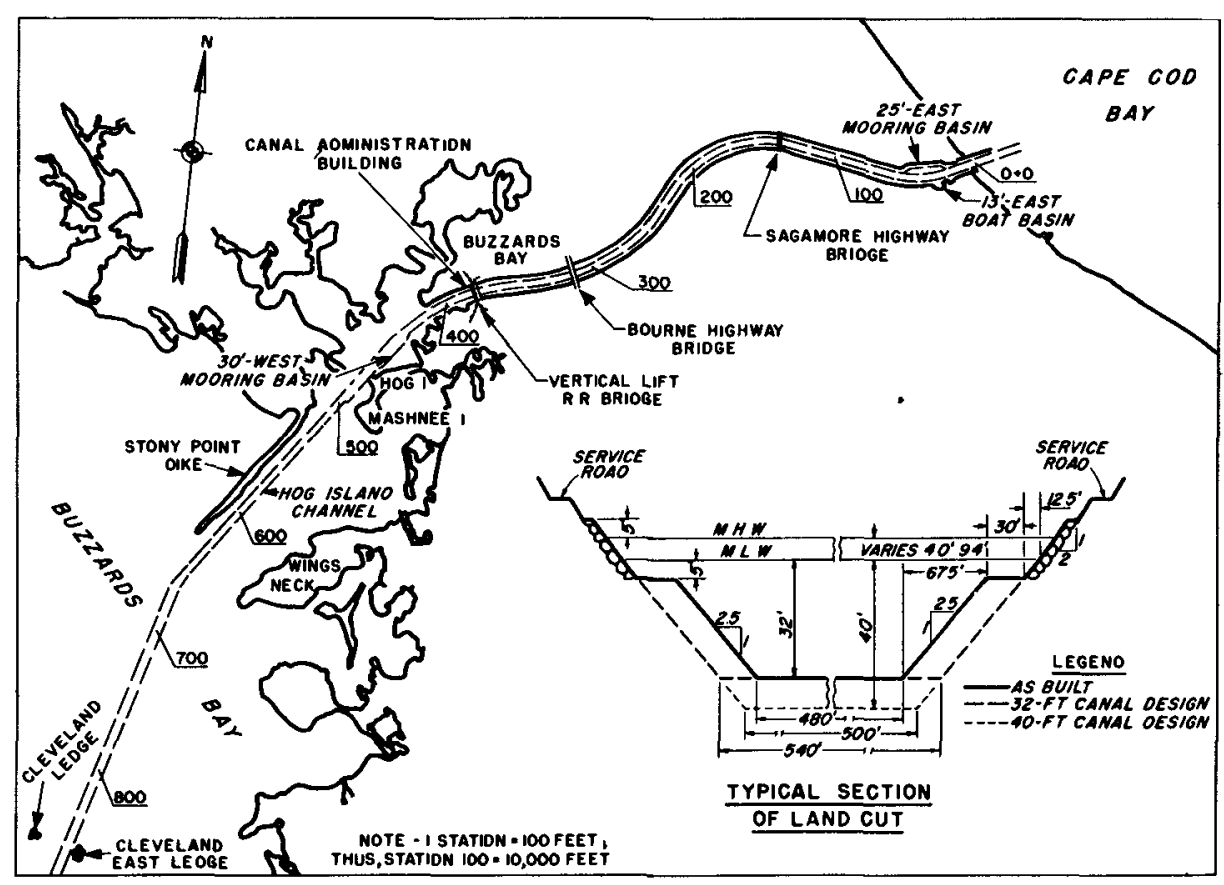

Fig. 2. Cape Cod Canal - plan and section. 
Cape. (See Figure 2.) This tortwous channel required navigating a zigzag course, frequentiy veeiring off on 50 degree tangents.

To make matters worse, currents in the canal ranged from 4 to 5 lonots. These currents were due principelly to the variation between the 4-foot tide at Buzzards Bay and the 9.4-foot range at Cape Cod Bay. In addition, the Buzzards Bay tide precedes the Cape Cod Bay tide by about 3 hours, further complicating the problem. Due to the se strong tidal currents and the limited channel width, several serious accidents to shipping occurred. Within a few months of opening of the Canal, two separate ship sinkings occurred, each occasioning a loss of $\$ 275,000$. One ship blocked the channel for three months. From 1915 to 1930, 75 acaldents were reported for a total 1088 of $\$ 800,000$. The narrow width limited the Canal use to one-way traffic, with resultant narigation dolays and inconveniences. It did not take long for the canal to develop a bad reputation with mariners, and shipping and tolls failed to meet expectations.

The owners, having what then proved to be an uneconomical investment, sold out to the Federal Goverment for $\$ 11,500,000$ in 1928 after eleren years of negotiations. Under the particular circumstances, it is not surprising that the local interests relaxed their traditional opposition to Federal intervention and endorsed Federal assumption of a waterway project of doubtful merit. The purchase of the Canal by the United States was made with the full knowledge that it rould require considerable improvement to be a practicable waterway.

Two alternative plans of improvement of the waterway by the Governnent were considered and model studies made of each. The plen initially recommended in 1931 provided for its modification to a lock canal 32 feet deep, generally 250 feet wide. The lock itself would have the same dimensione as those in the Panma Canal, 40 feet deep, 110 feet wide, and 1,000 feet long. The lock was designed with both middie and end gates for ships not requiring the full length. Tests were made for lifts from 3 feet to 7 feet, the ordinary differences in tidal elevations at any one tive be tween Cape Cod Bay and Buzzards Bay. Tests were also made for a lift of 12 feet, which is greater than any knom instantaneous storm head.

The test ohip was a model similar to the standard type of cargo ressel, but 600 feet long, 75 feet wide and loaded to 35,000 tons displacement. These dimensions are larger than those of most cargo vessels in use today. Tests were made on a scale of 1 to 40. It was found that the lock could be filled in 7 minutes for the 12-foot lift with resultant stern haurser forces of 15 tons. These results were considered entirely satisfactory. Construction of a lock would make the Canal practically currentless, enabling safe two-say traffic in a 250-foot width.

Experience gained in operating the Canal from 1928 to 1934 and the low costs incurred in widening the channel to 170 feet by that date, led to a remexandnation of the relative merite of a lock canal as compared 
to a seamlerel canal. It was found on this re-analysis that a sea-level waterway would be more economical and would possess certain advantages over a lock canal. The design of the sea-level canal provided for a depth of 32 feet and a width of 540 feet. This width was primarily establi shed to allow a future Canal width of 500 feet at a depth of 40 feet. (See Figure 2.) A width of 500 feet was greater than the length of ships ever expected to use the canal. In the event a ship ever got caught in the current, it could not suring sideways and ground out at both ends, damming the Canal. This proposed width was considered sufficient to afford safe two-way traffic, despite the strong tidal currents involved. The layout of the Canal was auch that the sharpest curves were of a radius of curvature of a mile and a half.

The model study for the seamlevel waterwy was made in 1935 by the Massachusetts Institute of Technolog under contract with the Corps of Bngineers. A model about 111 feet long and 34 feet wide was constructed, reproducing the waterway at a horizontal scale ratio of 1 to 600 and a vertical scale ratio of 1 to 60 . Three different chamel sections were studied as follows:

1. The 170-foot by 25-foot canal section then extisting.

2. I 500-foot by la-foot Canal.

3. A 540-foot by 32-foot Canal.

The study of the 170 foot by 25 -foot Canal section was made with a tide homologous to that observed December 21, 1934. Observations at 9 points along the length of the model were correlated with observations taken at identical stations along the prototype. The then exdisting bridges, with drem openings of 140 feet, and approaches on closely-spaced pile bents, were simulated by sills in the model, causing equivalent loss in head. Boulders of 1-1/2 cubic jards or more in size, scattered along the bottom of the Canal at locations known from dredging records, were simulated in the model by stones of $3 / 4$ inch to $2-1 / 2$ inches in size.

Comparison of high and low water profiles of the model and prototype and the profiles at times of maximum head indicated an average difference in water surface elevations of 1 ess than 0.1 foot with a maximum difference of less than 0.5 foot. Upon completion of the initial tests, studies were then made on the 500 by 40 -foot section and the 540 by 32 -foot section. These studies of the enlarged sections were made with a stral ght approach channel through upper Buzzards Bay, rather than the previous zig-zag approach. The studies were made both with and without dikes alongside the proposed Buzzards Bay straight approach channel.

It was found that the 40-foot Canal would have a low-rater profile up to 0.5 foot higher in the easterly 4 miles of the Canal, and up to 0.3 foot lower from there to the State Pler at the west end of the land cut of the Canal. However, the 32-foot Canal would have a low-water profile generally about 0.3 foot lower then in the existing $25-f 00 t$ Canal. The velocities for mean tides would range from 2 to 3 knots in 
both enlarged Canals, a reduction of 20 to 40 percent from the velocities in the 170 by 25-foot Canal, resulting from the observed tide of December 21, 1934. Unfortunately, no measurenents were made in the model of the 170 by 25-foot Canal based on mean tides, so it is not possible to state exactiy how much of this decrease in velocity is due to the difference between the tide of December 21, 1934 and meen tides, and how much is due to the change in Camal section. The tide of December 21,1934 was roughly ten percent greater than a mean tide.

It was determined that the greater part of the reduction in velocities was due to construction of dikes alongside the approsch channel in upper Buzzards Bay. The se dikes in effect extend the length of the Canal proper about 1-1/8 miles, or about 15 to 20 percent, thereby reducing the slope and velocities an equivalent amount. However, the dikes were built primarily to eliminate hazardous cross-currents in the approsch channel. These cross-currents resulted from a large part of the tidal flow followIng the old gig-rag approach channel bed.

The model tests proved concluaively that an enlarged sea-level Canal was entirely practicable, and construction was initiated.

Bxperience gained in construction of the original Canal demonstrated that excavation in the dry was more economical than dredging. This procedure was followred insofar as it was practical. Examination of the orlginal waterway indicated that it would be necessary to revet the banks 5 feet above mean high water to 5 feet below mean low water to prevent exosion of the banks and consequent shoaling of the canal. The design found most suitable was 18 inches of riprap, the stones being rum of the quary ranging from 50 to 300 pounds each, laid on a 6-inch blanket of cruhed stone. In areas where excavation in the dry below low water was impracticable due to the proximity of the exdisting Canal, the riprap was hand-placed down to mesn low water, and then a sufficient volume of stone was dumped against the bank. The theory was that gradual erosion of the bank below 1 ow water in that area would cause the stone to settle into place, stopping further erosion.

Approximately 54,000,000 cubic yands of excavation were involved in the construction of the Canal, including 15,000,000 cubic yards in the original channel. This is about one-fourth of that required in the construction of the Panama Canal. Approximately 15 percent of the material was excavated in the dry, 30 percent by hydraulic dredges, and 55 percent by dipper dredges. The construction by the Govermment was conmenced in 1932 and completed in 1940. The final width obtained was 480 feet, making the Cape Cod Canal the widest in the world.

Two high level fixed highway bridges and a vertical lift railroad bridge were constructed over the Canal at the time it was widened. These bridges were designed to permit a clear channel width of 500 feet, and are 135 feet above mean high water. Protective riprap about the bridge piers has decreased the horizontal clearances at the channel bottom to 


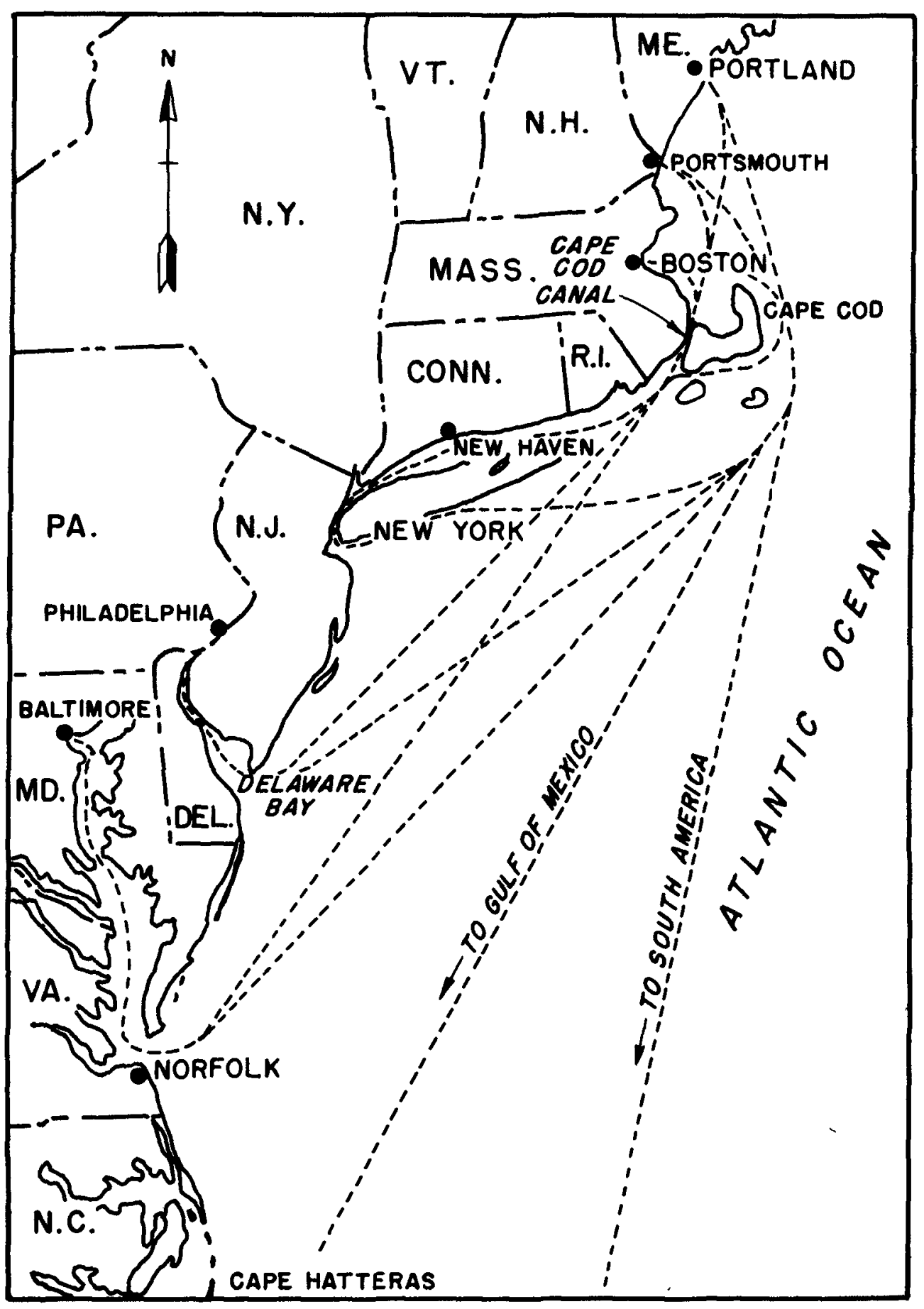

Fig. 3. Soa lanes - traffic passing Cape Cod. 
465 and 480 feet. The 500-foot lift span of the rallroad bridge is the longest such span in the world.

Having reviewed the history leading up to the building of the Canal, and the design and construction of the canal, our interest now turns to the benefits realied frcm this waterwey project.

Since the purchase by the Goverrment in 1928, the annusl tonnage shipped through the Canal has increased about 9 times, or from $1,500, \infty 0$ tons to $13,500,000$ tans. The present volume is about half of that carried by the Panama Canal and about equal to that carried by the Welland canal in Canada. The number of ship transits per year in the cape cod Cenal have increased since 1928 about 50 percent, from 9,500 to 13,500. It 18 obvlous that the size of the ships using the canal has noticeably increased, the average tonnage per ahip being 6 times that formeriy carried. It is interesting to note that the growth of total volume of commerce has far exceeded the population and Industrial grourth of Ver Ingland, Indicating a shift to the Camal by commerce formorly travelling other routes. This expanding use is the best proof of the econcanic value of the Canal.

The increase in the average 20 of the ships reflects the transition from the moderate-sized barge and packoge freight steamer to the bulk carrier, and the continuous growth in size of these bulk carrlers. The design of the Camal was evidentiy successful beyond original anticipation, as it is now daily used by vessels larger and more heavily laden than contemplated in the construction of the canal to its present dimensions.

The waterway saves from 65 to 150 miles in navigation distances, depending upon the perticular route that mi ght otherwise have been used. (see Figure 3.) This saving in distance is a significant percentage of the total shipping distances to the Atlantic coast and Culf ports. If an average saving in distance of 100 miles is assumed, there is a total annual saving for the deeper draft ships using the Canal of well orer 500,000 miles. Although exact figures of savings could not be obtained without a laborious compliation of statistics, it is conservatively estimated that over $\$ 3,000,000$ a year is sared in shipping costs due to time sapings alone. This figure can be substantiated by relatively simple computations. Let us assune that the entire 13,000,000 tons of comerce passing through the canal is carried in the larger ships known to be the more econondcal to operate per ton mile. There are 5,000 ahips per year of greater than 15-foot draft using the Canal. That would indicate an average cargo per ship of 2,600 tons which would appear reasonable when it is considered that a good deal of the cammerce to New England is one way comerce such as coal and oil, and the ships retum empty. The class of ressels concemed has an average speed of about 12 knots. Therefore, the 100 mile saving in distance would anount to about $8-1 / 3$ hours' time. Operating costs of these ships arerages about $\$ 75$ per hour. Bech ahip, therefore, would save $\$ 625$, or the 5,000 sinps would save $\$ 3,125,000$. 


\section{COASTAL ENGINEERING}

The Federal Government has expended about $\$ 43,000,000$ to date on Cape Cod Canal as followr:

\author{
Purchese price \\ Improvement of the Camal \\ Malintenance since 1928 \\ Operation since 1928
}

$11,500,000$
$20,000,000$
$5,700,000$
$5,800,000$

Therefore, the average total amual costs of the canal, incluting interest and amortization of the Federal investment and annual maintenance and operation cost 8 , anount to less than $\$ 1,500,000$, or less than half of the value of the annual saving in shipping time. Of even more importance, however, is the benefit due to avoldance of the hazardous route around Cape Cod. For the 20 years preceding the original construction of the Canal, on average of 50 ships a year were wrecked rounding Cape cod, with an annual loss of life of 15 persons, and an annual 1058 of ressels and cargoes of well over $\$ 500,000$.

It is true that the Conal itself has not been without accidents, particularily before its purchase and widening by the Goverment. However, the amual number of accidents or wrecks in the canal up to the time of its purchase by the Goverment was 6 and the average amual value of losses or damages suffered was about $\$ 75,000$. No loss of life was recorded. Since completion of the Canal widening in 1940, there have been an average of less than 3 accidents or wrecks per year, mostiy minor in nature, for an anmual loss suffered of $\$ 50,000$. This flgure is exclusive of the sinking of the Arizona sword in 1951 at a net 10 ss of about $\$ 500,000$. The cont ributing factors in the sinking of that vessel are presently being investigated and there is an element of doubt as to whether this loss can be fairly attributed to navigation conditions in the Canal.

You will appreciate that the Canal is particularly raluable in time of war affording a protected route safe from submarine attack. It mi ght be well to state at this time that the tomage figures previously given do not include military and naval ressels.

Congress has directed the Corps of Engineers to ascertain whether or not the existing project should be modified. You will recall that I stated that the width of the waterway was determined in 1935, and was based on the expectation that ships of greater than 500-foot length would not use the Canal. The standard deep-draft vessel of that period drew 25 feet. However, ships bullt since 1935 generally have been of lengths greater than 500 feet and drafts of 30 feet or more. As the older ships are replaced, the merchant fleet is rapidly becoming predominantly characterized by ships beyond the design capacity of the Canal.

It has been claimed that only 40 percent of the deep-draft ships 


\section{CASE HISTORY OF THE CAPE COD CANAL}

which might use the Canal do so. It is known that fully loaded deep-draft tankers usually avoid the Camal. This is borne out by the fact that about 60 percent of the coastind se cormerce in the Port of Boston is in petroleum as compared to 15 percent of the canal comerce. It will be recalled that two large tankers, the Fort Mercer and the Pendleton, broke in half off Cape Cod in the same storm in February 1952. Both tankers were fully loaded with oil from Louisiana. One tanker was headed for Boston, one for Portland, Maine. Over 50 lives were lost on this one occasion. It should be recognized that all the traffic passing Cape cod will probably never go through the Canal. In certain cases, such as ships arriving from some South American ports, the direct route may be east of the Cape. However, it is probable that the present depth is a factor in the limited use now made of the Canal. Therefore, in view of presently changing conditicns, re-study of the Canal design at this time is highly desirable. As a basis for this study of possible future deepening or enlarging of the Canal, a more detailed review of the prevlous design, construction experience, and actual resulting conditions should prove of $v$ alue.

The Canal was dredged to a width of 480 feet rather than the 540 feet originally contemplated. (See Figure 2.) Berms 30 feet wide, 5 feet below mean low water, were left on both sides of the Canal to protect the revetment until additional experience could be gained as to bank erosion that might occur. The revetment was generally placed as originalif planned, from 5 feet below mean low water to 5 feet above mean high water. The Canal benks at mean low water are 700 feet apart, the width designed to permit a 500-foot chamel width at a depth of 40 feet, with banks sloping one vertical on $2-1 / 2$ horizontal.

The maximu velocities experienced in the canal range from 3.5 to 4.0 knots, or roughly about 10 percent less than in the original waterway, and roughis about 10 percent more than indicated by the model tests for a Canal 32 feet deep and 540 feet wide.

The annual maintenance of the Canal has averaged about $\$ 225,000$ since its purchase by the Government in 1928. This figure has remained uniform throughout the period of Federal ownership of the Canal despite decline of the dollar value. This $\$ 225,000$ includes maintenance of the bridges, roads, and buildings as well as maintenence of the Canal itself, but excludes an mnual cost of $\$ 250,000$ for purely operational purposese Maintenance of the channel depths over the past ten years has required dredging an average of 350,000 cubic yards of material a year at an annual cost of $\$ 90,000$. Maintenance of the 100-foot Camal from 1916 to 1928 had required an average anmual dredging of 250,000 cubic yards. Thus, it is seen that the increase in channel maintenance has been proportionately wuch less than the increase in the channel width. Comparl son of channel surveys of different years indicates an average amual erosion, or scouring, of the channel bottom of 370,000 cubic yards. However, this rate of ero sion is apparentiy diminishing, the volume in the 4 years 1944 to 1948 being about half that in the first 4 years of the completed Canal, 1940-1944. Although the Canal was only dredged to a depth of 32 feet, holes 20 to 30 
feet below the channel bot ton have scoured out at several locations. There are at least 15 different locations were this scour occurs. One of these holes is more than a mile long. The reasons for the scour at the particular localities is not readily apparent. At some of the locam ticans there is an irregula rity in the Canal section, such as at the east end of the Canal at the jetties, and were the Canal widens at the mooring basins. Some of the exoded areas are in the vicinity of structures built within the canal priam, such as at the bridge piers and the bulkhead at the state Pler. However, at about half of the locations there is no evident reason for exosion. No detailed study has beem made of the character of the bottom materials at the various locations along the channel, which might explain the areas of eroston. It would appear from comparison of the volumes of charmel scour and chamel shoaling that the material eroded from the channel bottom remains in the channel, depositing at various points to form shoals.

Despite the berms and revetment protecting the canal banks, some erosion of these banks has occurred. This erosion has principally occurred on the outer bank at the Canal curres. Bank restoration and stabilization costs have averaged about $\$ 40,000$ a year over the past 8 years. It is not considered that the erosion is due in any large part to the wash from ships. Regulations have been established to permit restriction of ressel speed to 9 knots at slack water, or 6 knots against the current and 12 knots with the current. However, it has not generally been found necessary to exercise these restrictions and within reason, the ship master is permitted to use his orn judgment as to proper ship speed for safe navigation.

What can be learned frcm this project revien? It is dangerous to attempt to draw conclusions of general applicabllity from the history of one waterway project. Local conditions and numerous other factors make each project a unique study in itself. However, experience can and should serve as a guide, if viewed carefully as to particular conditions affecting the project. For instance, the Cape Cod Canal project was studied and was the subject of proposed construction over a period' of some three hundred years. The volume of coastivise comerce, the size of ships in this traffic, and their propelling power and navigating character istics, changed considerably orer this period. It is fairity obvious why a sea-ievel Canal with its attendant tidal currents was not even conoddered during the era of salling craft prior to 1860. The disadvantages of the navigation conditions of a tidal canal steadily diminished in inportance as the merchant fleet became characterized by the more powerful and more easily handled steamers and motor vessels. However, even up to the purchase of the Canal by the Govenmment in 1928, opinion leaned toward a lock canal as preferable, perhaps partly because of the unsatisfactory experience with the narrow sea-level Camal since 1916. The unusual circumstance of the depression of the early nineteen-thirties, with funds made available for work projects that could be imediately undertaken, and the low excavation prices then obtainable, changed the economics of the picture. Largely because of these economics, but also 


\section{CASE HISTORY OF THE CAPE COD CANAL}

whth other factors in mind, the canel design was changed from a lock canal to the seamlevel canal.

The experience of the original 25-foot Camal, 100 feet wide, indicates that $a$ pro ject of scant dimensions is not necessarily an econcurs, and may in fact be wasteful and fail to develop the potential benefits.

Earlier studies of the Canal concluded that currents would be increased in a seaway canal of enlarged cross-section. However, these earlier studies did not take into account the modification of tidal head that would result from the crmal enlargenent. The model study, undertaken as the only means of determining the total effect of the canal enlargement, indicated currents in the enlarged Canal would be of the same order of magnitude as in the existing Canal. The model tests further indicated the necessity of extending the waterway by dikes to eliminate hazardous cross-currents at its original mouth. The model test $s$ revealed that this extension of the Canal would decrease the currents 15 to 20 percent. The report on the model tests cautioned that the relocities be considered qualitative rather than quantit ative.

It is not yet definite whother the cenal has reached a stable condition, and whether the exi sting erosion and shoaling will continue. However, with the results of the previous studies, and with the 10-year experience of the 32-foot Canal, the present study of further enlargement of the Canal can proceed on a sound basis. It might be said then, on the basis of this case history, that modification of this Canal, or conistruction of any simflar navigation project, rests in order of importance upon the folloring:

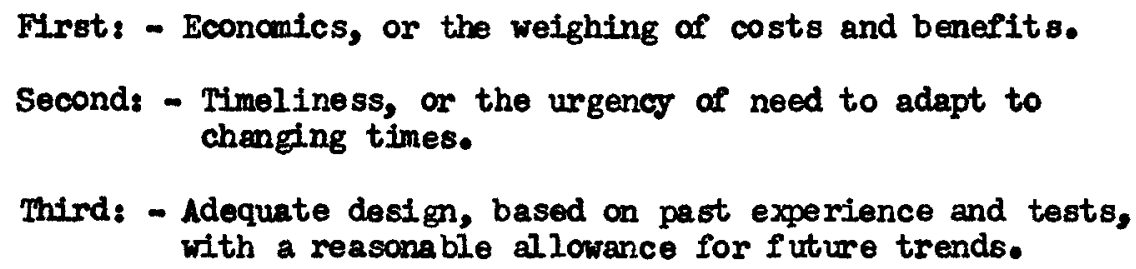

\section{REF EREATES}

Boston District, Corps of Engineers (1930). Report on Preliminary Examination and Survey of Cape Cod Canal, Massachusetts. House Document No. 795, 71st Congress, 3d Session.

Boston District, Corps of Engineers (1934). Review of Reports on Cape Cod Canal. House Document No. 15, 74th Congress, lst Session.

Horton, D. F. (1939). The Cape Cod CanaI. Boston District, Corps of Engineers. (unpublished). 
Mactean, A. R. (1939). Construxtion Plans and Methods, Cape Cod Caral. Boston District, Corps of Engineers. (unpublishod).

Reynolds, K. C. (1936). Report on Model study of Cape Cod Canal and Approache8. Massachusetts Institute of Technology. (unpublished).

Rich, G. Ro (1932). Model Tests of the Navigation Lock for the Cape Cod Canal, Massachusetts. Boston District, Corps of Engineers. (mpubli shed). 